\title{
Soil bioengineering and biomonitoring of vegetation and after-care at Wismut's backfilled and covered Lichtenberg open pit and its surrounding area, Ronneburg, Germany
}

\author{
U Barnekow Wismut GmbH, Germany \\ M Köhler Wismut GmbH, Germany
}

\begin{abstract}
Since 1991 the state-owned Wismut GmbH has been remediating the legacies of former uranium mining in Germany. In the Ronneburg area, uranium mining, including underground and open pit mining, lasted from 1951 until 1990. The Lichtenberg open pit was mined out between 1958 and 1977 and partly backfilled by 1990. From 1990 to 2007, the open pit was completely backfilled and re-contoured by relocation of more than 130 million $\mathrm{m}^{3}$ of mine waste dumps located in the surrounding area. A thick cover lat least $1.6 \mathrm{~m}$ deep), consisting of loamy soils, was placed on nearly the entire re-contoured backfill area, thus creating a new landscape. Only a small disposal area for radioactively contaminated mine wastes currently still exists on the pit's surface. Located next to the area of the Federal Horticultural Exhibition 2007 in Gera and Ronneburg, and the nearby town of Ronneburg (today with ca. 5,000 inhabitants), the newly formed hill 'Schmirchauer Höhe' competes with the highest natural hills in the surrounding area. The land use of the covered pit and its surrounds after closure includes forestation, grassland allowing for establishment of forest, open grassland and local park areas, barren land, wetlands and ponds. In addition, the re-use of the remediated mining sites in the surrounding area includes urban land use (dwellings), some industrial uses and renewable energy production with two large photovoltaic solar power plants that jointly cover ca. $37 \mathrm{ha}$. This paper presents the strategy and the steps for remediation including relocation of waste rock dumps for backfilling of the open pit and soil covering forming a new landscape. It puts specific emphasis on soil bioengineering strategies and methods applied for erosion control and establishment of vegetation (sowing strategies) in accordance with the requirements fixed in the accompanying landscape management plans for this and other sites. For about a decade, biomonitoring has been carried out on an annual basis, including biotope mapping and test pit excavations, to monitor the soil profile and root zone development in the soil cover over time. Based on the biomonitoring results, after-care measures have been implemented to allow and improve vegetation establishment and development. Nowadays some endangered species are colonising the newly formed habitats. The end of the remediation phase of the Lichtenberg open pit is a few years off. This allows for a preliminary review and outlook on the landscape development and its after-use in the future.
\end{abstract}

\section{Introduction}

In the Ronneburg area uranium mining lasted from 1951 until 1990. It ended immediately after the re-unification of Germany. Since 1991 the state-owned Wismut $\mathrm{GmbH}$ has been responsible for remediating the legacies of former uranium mining in Saxony and Thuringia. This paper presents the strategy and the work steps of the remediation of the Lichtenberg open pit, located within the Ronneburg mining area. It puts specific emphasis on aspects of landscape design and management, soil bioengineering and biomonitoring. The remediation included the relocation of waste rock dumps and backfilling of the Lichtenberg open pit and soil covering, thus creating a new landscape. In particular this paper presents the soil bioengineering strategies and methods applied for erosion control on the soil cover and for the establishment of vegetation (sowing strategies) to be implemented in accordance with the requirements fixed in the accompanying landscape management plans for this and other sites. The end of the 
remediation works is a few years ahead. This allows for a preliminary review and outlook on the landscape development and its after-use in the future.

\section{$2 \quad$ Mining history and site characterisation}

The Ronneburg mining area is located in Eastern Thuringia in Germany, in a hilly to mountainous topography with elevations ranging from ca. $238 \mathrm{~m}$ asl in the Gessenbach creek valley to the hill 'Reuster Berg', with an elevation of $370 \mathrm{~m}$ asl. The region belongs to a transitional climate zone of the temperate latitudes. The average annual temperature is $8.5^{\circ} \mathrm{C}(1966-2015)$. The measured average annual rainfall at the reference weather station nearby Ronneburg is $715 \mathrm{~mm}$. Rainfall generally occurs throughout the year.

The Lichtenberg open pit was mined out from 1958 until 1977 and partly backfilled by 1990. In 1990, besides the Lichtenberg open pit, the mining legacies in the Ronneburg uranium mining area comprised the surrounding underground mining area covering approximately $70 \mathrm{~km}^{2}$, including refillable open voids of ca. 25 million $\mathrm{m}^{3}$. The underground mine comprised 40 shafts with the deepest level of the underground mine at $-720 \mathrm{~m}$ below reference level at $300 \mathrm{~m}$ asl. Figure 1 is aligned northward. It shows the location of the backfill body above the Lichtenberg open pit and the subsurface areas of the relocated waste rock dumps (WRD) within the southern part of the Ronneburg mining area.

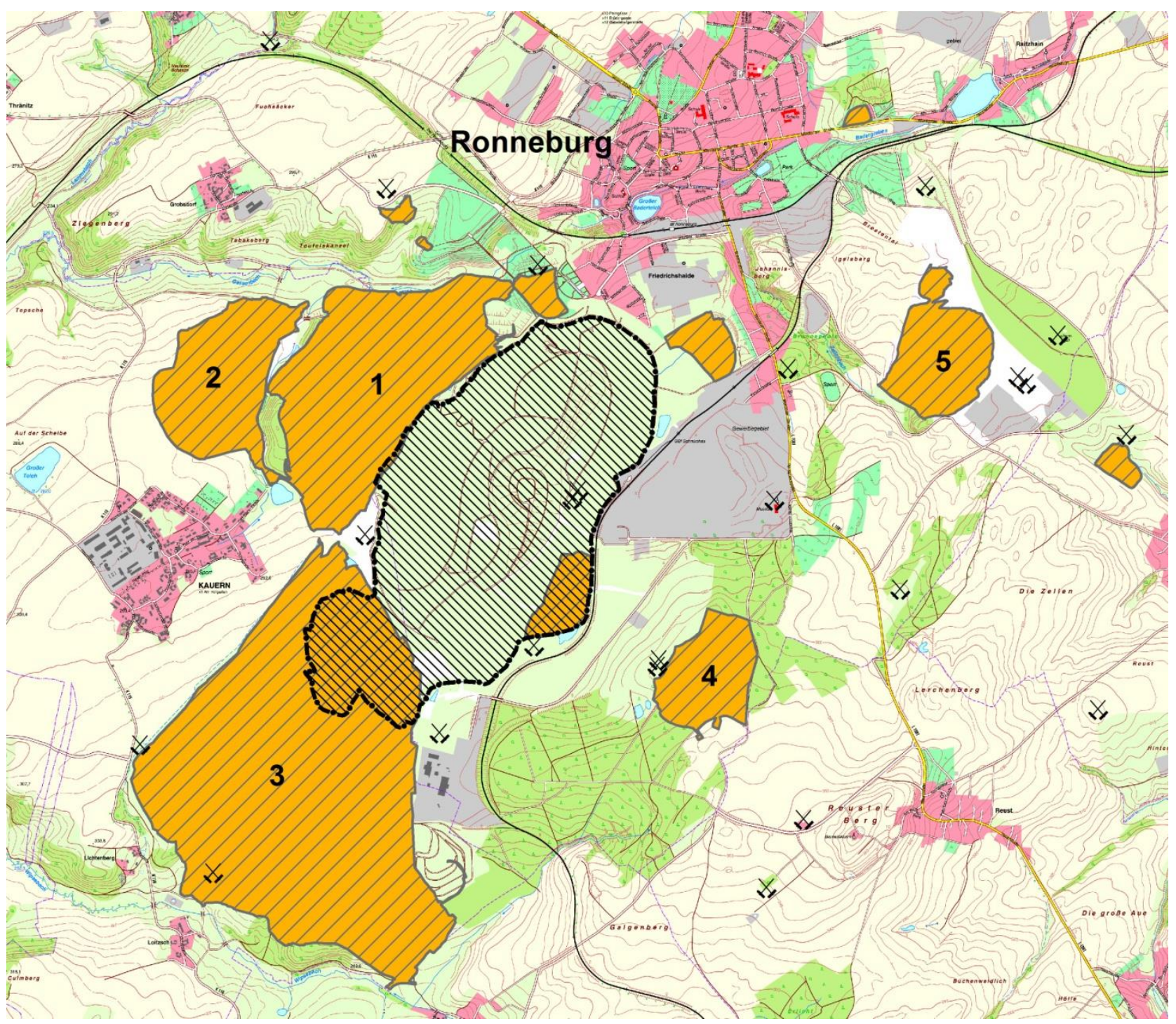

Dashed black line: borderline of backfill body of Lichtenberg open pit; $X \mathbf{y}$ := closed shaft; areas with inclined hatchures with numbers = dump subsurfaces (no.1 = WRD Nordhalde; no. 2 = WRD Gessenhalde; no. 3 = WRD Absetzerhalde; no. 4 = WRD Reust; no. 5 = WRD Paitzdorf)

Figure 1 Topographic map of the southern Ronneburg mining area in 2015 
The dashed black line on Figure 1 indicates the borderline of the backfill body of the former Lichtenberg open pit. It's area is marked by inclined hatchures and extends ca. $1.6 \mathrm{~km}$ from north to south. It covers an area of about $2.2 \mathrm{~km}^{2}$. The areas with inclined hatchures and numbers on the map in Figure 1 represent the subsurfaces of the relocated former waste rock dumps. The five largest dumps include the major part of the backfill volume in the open pit. They are indicated with numbers 1: WRD Nordhalde (vol.: $31.3 \mathrm{million}^{3}$ ); 2: WRD Gessenhalde (heap leaching facility; vol: 7.7 million $\mathrm{m}^{3}$ ); 3: WRD Absetzerhalde (vol. $70.0 \mathrm{million}^{3}$ ); 4: WRD Reust (vol.: 6.4 million $\mathrm{m}^{3}$ ); and 5: WRD Paitzdorf (vol.: 8.0 million $\mathrm{m}^{3}$ ). In addition, further smaller waste rock dumps were relocated (Figure 1). Figure 2 presents an aerial view on the Lichtenberg open pit, its surrounding waste rock dumps and a part of the mining area showing the status before remediation in 1990.

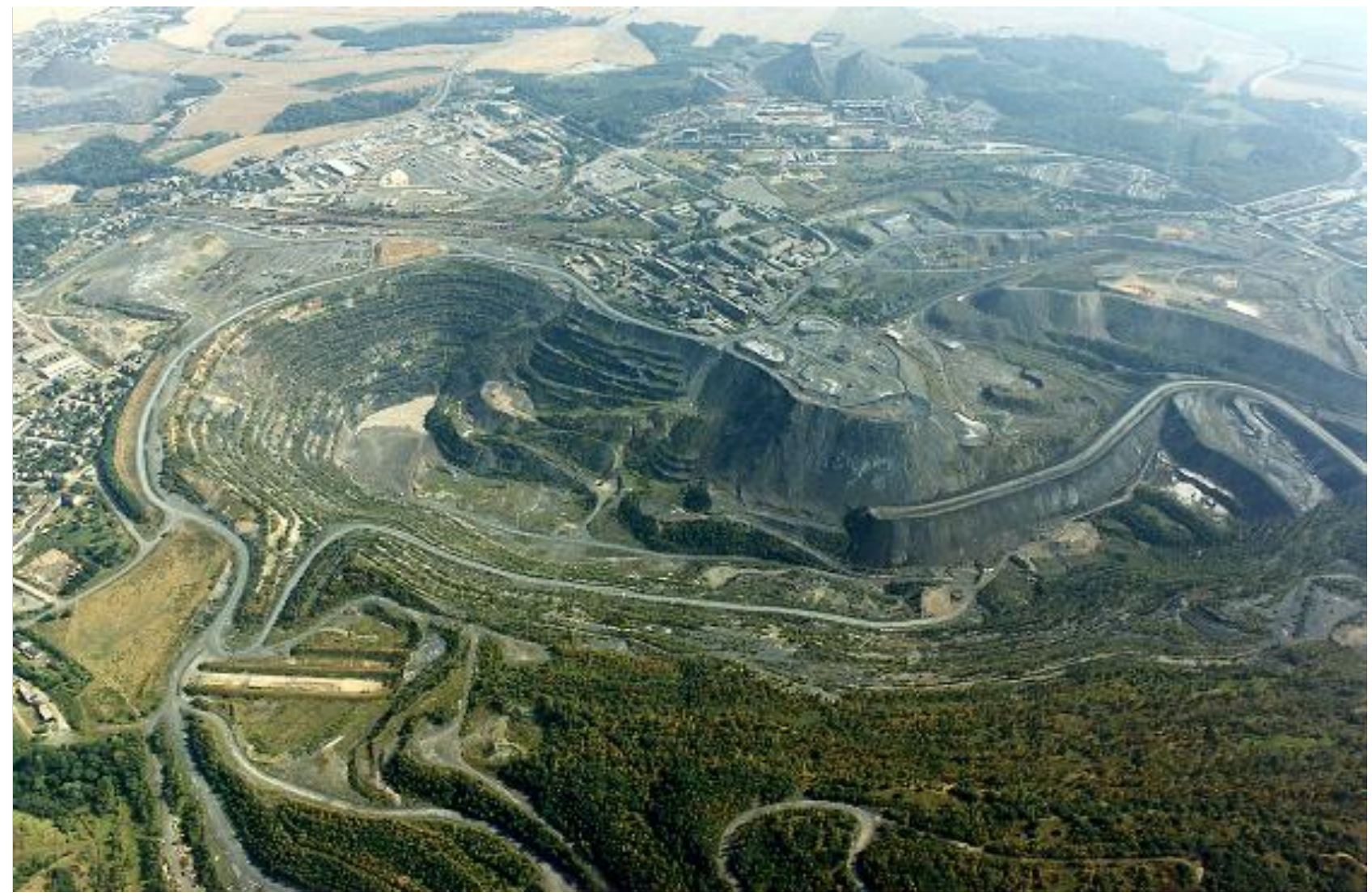

Figure 2 Lichtenberg open pit in 1990 (view from west to east)

The Lichtenberg open pit (Figure 2) was mined out to a maximum depth of $240 \mathrm{~m}$ below ground surface. It is located in the immediate vicinity of the Ronneburg town (Figure 1 and left side of Figure 2). Here several villages were demolished due to the mining activities, i.e. the villages of Schmirchau and Reust and the major parts of the Lichtenberg village located inside or in the nearby surrounding area of the Lichtenberg open pit. The waste rock from the open pit was dumped on several large WRDs in their immediate surrounding area. Figure 2 shows the Nordhalde WRD in the foreground (Figure 1: WRD no. 1); the internal waste rock dump 'Innenkippe' inside the Lichtenberg open pit and the conical piles; with Reust (Figure 1: WRD no. 4) in the background. In the area of the open pit the pre-existing underground mine workings were excavated completely. In 1990, the Lichtenberg open pit was $2 \mathrm{~km}$ long, $1 \mathrm{~km}$ wide and covered an area of about 160 ha. It was already partly backfilled with 76 million $\mathrm{m}^{3}$ of waste rock (WRD Innenkippe). The remaining volume of the pit was about 84 million $\mathrm{m}^{3}$. Figure 2 shows the destruction and total rearrangement of the former landscape and land uses by mining activities. In the Ronneburg mining area, contaminated mining sites and industrial sites, including all type of facilities, buildings, roads, railroads etc. covered approximately $10 \mathrm{~km}^{2}$. They are also located around the Lichtenberg open pit (Figure 2). Fifteen waste rock dumps in the area surrounding the Lichtenberg open pit and from the underground mining in the area included approximately 135 million $\mathrm{m}^{3}$ of waste rock or in total about 200 million $\mathrm{m}^{3}$, 
including the waste rock backfilled into the open pit (WRD Innenkippe), by 1990. In addition, a large heap leaching facility operated near the open pit on the waste rock dump 'Gessenhalde' (Figure 1: WRD no. 2). A landfill for sludge disposal and other disposal areas for different types of construction debris and wastes were operating on the WRD no. 3, named 'Absetzerhalde'.

During and after the operational phase, the mining activities caused an adverse impact on the population, miners, other workers and the environment. The dumped waste rock consisted of a mixture of crushed rock (blocks, stones, gravel, sand and some silty-clayey fraction). The mine wastes comprised for the most part of shales, limestones and diabases with pyrite contents of up to 7\%. Due to weathering, some poorly vegetated raw soils developed on the dump surfaces. The mining activities and the exposed surfaces of the waste rock dumps and of the excavation areas caused radioactively contaminated dust. In addition, radon emissions from the ventilation shafts and waste rock dumps affected the workers and the population. Acid generating weathering of iron sulphides, accompanied by highly mineralised seepage contaminated with heavy metals and radionuclides, caused the most serious environmental problems which impacted on the general remediation strategy. The effluents from the mines caused massive emissions into the receiving streams in 1990, e.g. $8 \mathrm{t} \mathrm{U}$ per year. The weathering of the most acid generating waste rock materials heated up large volumes of the waste rock dumps. Even before open pit mining started, numerous older underground mine workings, i.e. the entire underground mine of 'Old Lichtenberg', had to be abandoned due to underground mine fires. As a result, the 'Old Lichtenberg' underground mine had to be completely backfilled from the surface using pulps consisting of water, sand, loam and ashes from lignite burning power plants.

Some measures to reduce these acute dangers to the population and to the economy were already implemented during the operational phase. In order to mitigate the acute risks from radioactively contaminated dust and to reduce the environmental impact, some of the large dumps located next to the Lichtenberg, open pit were already covered with loamy (clean) soils during the operational period, like the Nordhalde WRD (Figure 1: WRD no. 1), and a part of the Absetzerhalde WRD (Figure 1: WRD no.3). On these surfaces, forests established naturally within a few years. Also water reservoirs were constructed, financed by the Soviet-German Wismut company, in the upper catchment area of the main receiving river Weisse Elster to reduce the hardness and salt concentrations in order to protect the existing industrial production downstream. Before 1990 this decision was driven by economic aspects. Environmental protection or ecological aspects were of minor importance.

From a geotechnical point of view, the ground surface sustained damages, including subsidence, sinkholes, deformations of the surface, and local slope failures and landslides. In 1966 a giant landslide (vol.: 9 million $\mathrm{m}^{3}$ ) of the Nordhalde waste rock dump (vol.: 31 million $\mathrm{m}^{3}$ ) filled a part of the adjacent Gessenbach creek valley near the Ronneburg town (Figure 3). It destroyed some houses and the railroad connecting Ronneburg with the neighbouring City of Gera. By 2007 this area was remediated and became the southern partial area of the Federal Horticultural Exhibition. It is located along the Gessenbach creek valley near to Ronneburg and Gera. Figure 3 also depicts the character of the waste dumps' raw soil surfaces. 


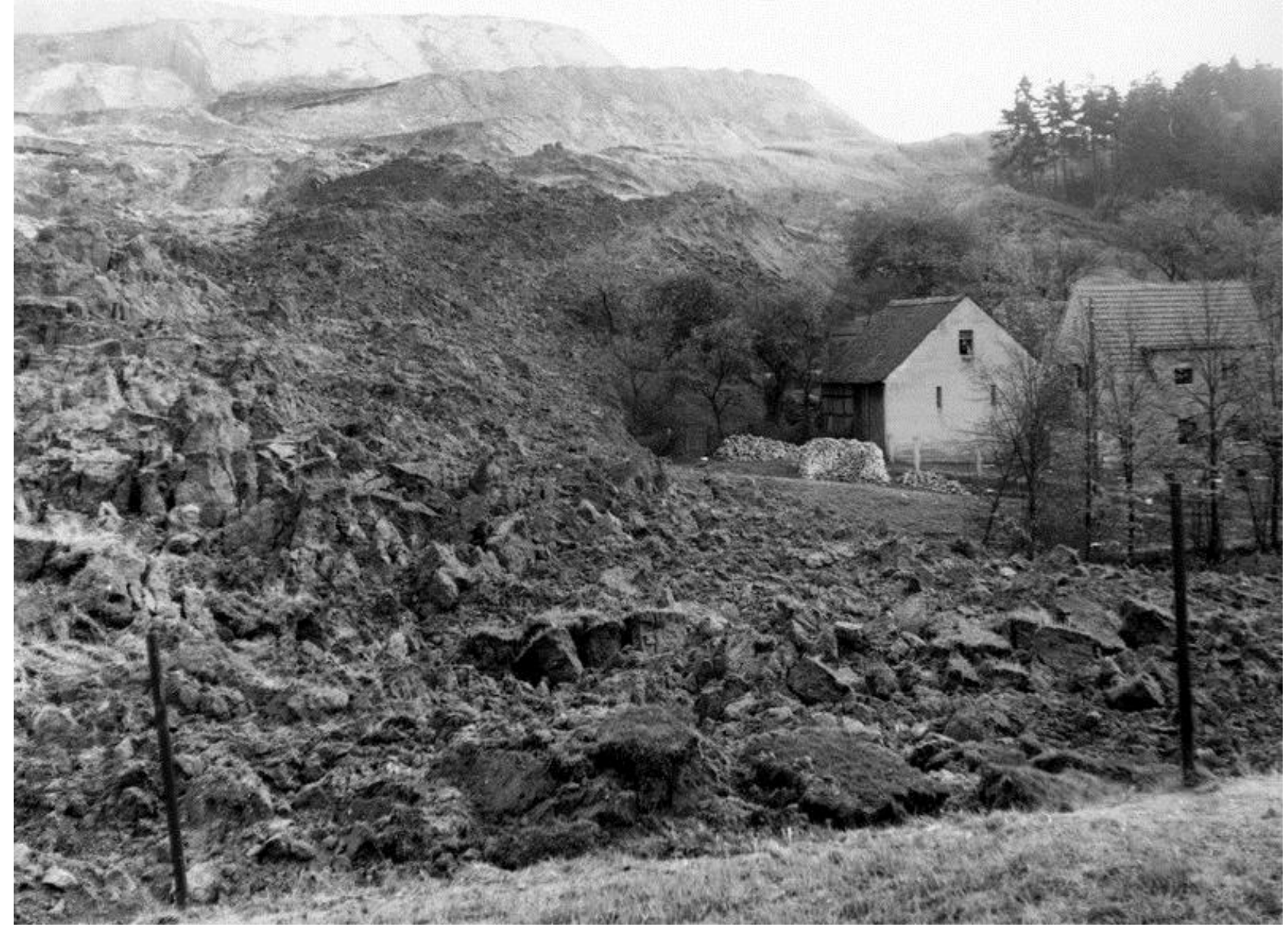

Figure 3 Landslide of the northern part of the Nordhalde waste rock dump in 1966

\section{Legal requirements and permitting procedures}

As for any mining site in Germany, according to the German Federal Mining Act (Bundesberggesetz), the remediation of the Lichtenberg open pit and its surrounding mining sites should try to eliminate any considerable residual risk on site or from the site to public safety, in particular with respect to securing geomechanical stability. In addition, the site should be prepared for re-utilisation after closure in compliance with regional land use concepts. The backfilling of the open pit was permitted as part of the Closure Operational Plan, according to paragraph 53 of the Federal Mining Act in 1992. The overall remediation was completed by individual mining remediation projects within the Closure Operational Plan.

The German Federal Water Act (Wasserhaushaltsgesetz) requires groundwater and surface water protection related to quality (chemical and physical including radiological parameters) and quantity (flood protection, required minimum flow rates). Requirements for waste water discharge into the receiving streams are set by the authorities of Thuringia. In addition, soil protection is required according to the water and soil protection laws. Permits under the water law were applied for and received for backfilling the waste rock dump material into the open pit.

According to the radiation protection law, remediation has to meet the requirements of the Federal Radiation Protection Act and specific subsidiary regulations from former German Democratic Republic, which are still in force to date, i.e. the "Directive for granting atomic safety and radiation protection" (VOAS 1984) and the "Directive on waste rock dumps" (HAO 1980). Permits were needed for:

- Using radioactive material above the clearance limit of $0.2 \mathrm{~Bq} / \mathrm{g}$. 
- Meeting the critical values for radiation protection for occupationally exposed workers and limiting the effective dose for individuals of the public below $1 \mathrm{mSv} / \mathrm{a}$.

- Justification of the remediation measures applied for the public's benefit.

- Optimisation of the remediation measures with respect to aspects of radiation protection, environment and cost-benefit.

Evaluations had to be carried out for the individual remediation projects as well as for the entire remediation at Ronneburg. In 2002 Wismut applied for planning approval for the remediation of the Lichtenberg open pit including the construction of final contouring (new landscape topography), covering and vegetation, preparations for after-use of the different individual areas and for containment of surface runoff and diversion to receiving streams. This included measures for flood prevention; construction of runoff retention pond $Z$ next to Ronneburg town. After having received 11 interim permits, Wismut received final planning approval in 2009.

\section{$4 \quad$ Remediation}

A fundamental prerequisite for the rearrangement of the landscape affected by mining is the development of a remediation strategy. After the end of mining, extensive investigations were carried out between 1992 and 1996 on waste rock material to determine key geochemical and soil physical parameters. The investigations included the review of historical and geological information, drilling of boreholes, excavation of test pits, different types of laboratory tests including column tests (elution tests) and lime addition tests. Based on intensive cost-benefit-analysis, the relocation of the waste rock into the Lichtenberg open pit was chosen as the preferred remediation option for more than $90 \%$ of the waste rock. The remediation strategy to relocate most of the waste rock dumps located in the southern part of the Ronneburg underground mine field into the open pit was selected because:

1. It fulfils the principle to concentrate the contaminants and results in reduced after care costs.

2. It gives results in the lowest emissions into the groundwater body, thus meeting the protection requirements of the Federal Water Act and the European Water Framework Directive.

3. It results in long-term yields that are equal to or lower than, when compared to alternatives.

4. It meets the principle of sustainability.

The remediation strategy for the entire southern part of the Ronneburg mining area included:

1. Securing measures in the underground mine and above-ground.

2. Water containment and treatment.

3. Relocation of most of the waste rock dumps and selective backfilling of the open pit including creation of a new landscape above ground.

4. Clean-up of contaminated subsurfaces of the relocated waste rock dumps and other mining sites.

5. Construction and operation of a waste depository for mixed-contaminated wastes.

6. Flooding of the underground mine, including all the preparatory and accompanying measures needed.

7. Monitoring during and after remediation.

The landscape and cover design, including re-vegetation, is a fundamental part of the remediation concept. It aims at controlling percolation and the water balance in both soil and cover profiles, and it aims at allowing different land uses of the landscape. The vegetation is an integral part of the remediation.

As the mobility of radionuclides and heavy metals depends essentially on the degree of acid generation of the waste rock, the prediction of its long-term geochemical behaviour was highly significant for 
remediation planning. The spatial variability of material properties could not be ascertained in sufficient detail from drilling data. Hence, the waste rock material and (contaminated) soil material were classified using a combination of paste $\mathrm{pH}$ and NAP $\mathrm{pH}$ methods, resulting in a classification scheme drawn up in 1996 that allowed for the selective relocation of waste rock material into the Lichtenberg open pit. According to their acid generating potential, the waste rock to be relocated into the open pit was classified as type A-, B- or C-material. The most acid generating material (type A) was relocated into the bottom part of the open pit. During placement in the pit lime was added to this A-material. The type A-material was placed below the future groundwater table planned to be reached after flooding. The neutral material (type C) was placed as a minimum 10 m thick top layer underneath the soil cover. The targetted placement into the pit allowed for the minimisation of contaminant release into the groundwater.

From 1990 until 2007, the Lichtenberg open pit was completely backfilled and re-contoured by relocation of more than 130 million $\mathrm{m}^{3}$ of waste rock dumps located in the surrounding area. Located next to the area of the Federal Horticultural Exhibition 2007 in Gera and Ronneburg and nearby Ronneburg town (today ca. 5,000 inhabitants), the newly formed hill 'Schmirchauer Höhe' (373 m asl) competes with the highest natural hills in the surrounding areas. The area of the former landslide of Nordhalde WRD presented in Figure 3 was completely relocated. In memory of the mining history and the waste rock dumps, the landscape planning for the Federal Horticultural Exhibition in Ronneburg and Gera in 2007 prescribed a newly designed artificial landscape with berms and slopes.

A thick cover at least $1.6 \mathrm{~m}$ deep, consisting of loamy soils, was placed on nearly the entire re-contoured backfill body. Only a small disposal area for radioactively contaminated mine wastes still remains on the pit's surface. Together with hydraulic measures, this approach should meet any requirements in terms of radiology, water protection, stability, erosion protection, and reuse.

The topography of the newly constructed landscape is a hilly landform diverting any runoff from the centre to the surrounding area. The underlying backfill body submerges into the groundwater table with a watershed inside the pit area. This minimises groundwater flow through the backfill body. The established vegetation on the cover supports the minimisation of percolation through the cover. In particular, forests are used as a supporting measure to minimise infiltration.

Besides the technical aspects of the cover design, detailed investigations on ecological and landscaping aspects were carried out to improve the visual impression, and the integration of the new constructed landscape into the surrounding regional landscape. According to the approved accompanying landscape management plan, the land use of the covered pit and its surrounding area after closure includes forestation, grassland allowing the establishment of forest, open grassland and local park areas, wetlands and ponds. In addition, the re-use of the remediated mining sites in the surrounding area includes urban land use (dwellings), some industrial uses and renewable energy production, with two large photovoltaic solar power plants with a combined area of about 37 ha. Figure 4 shows the landscape management plans for the mining sites in the southern Ronneburg mining area. 


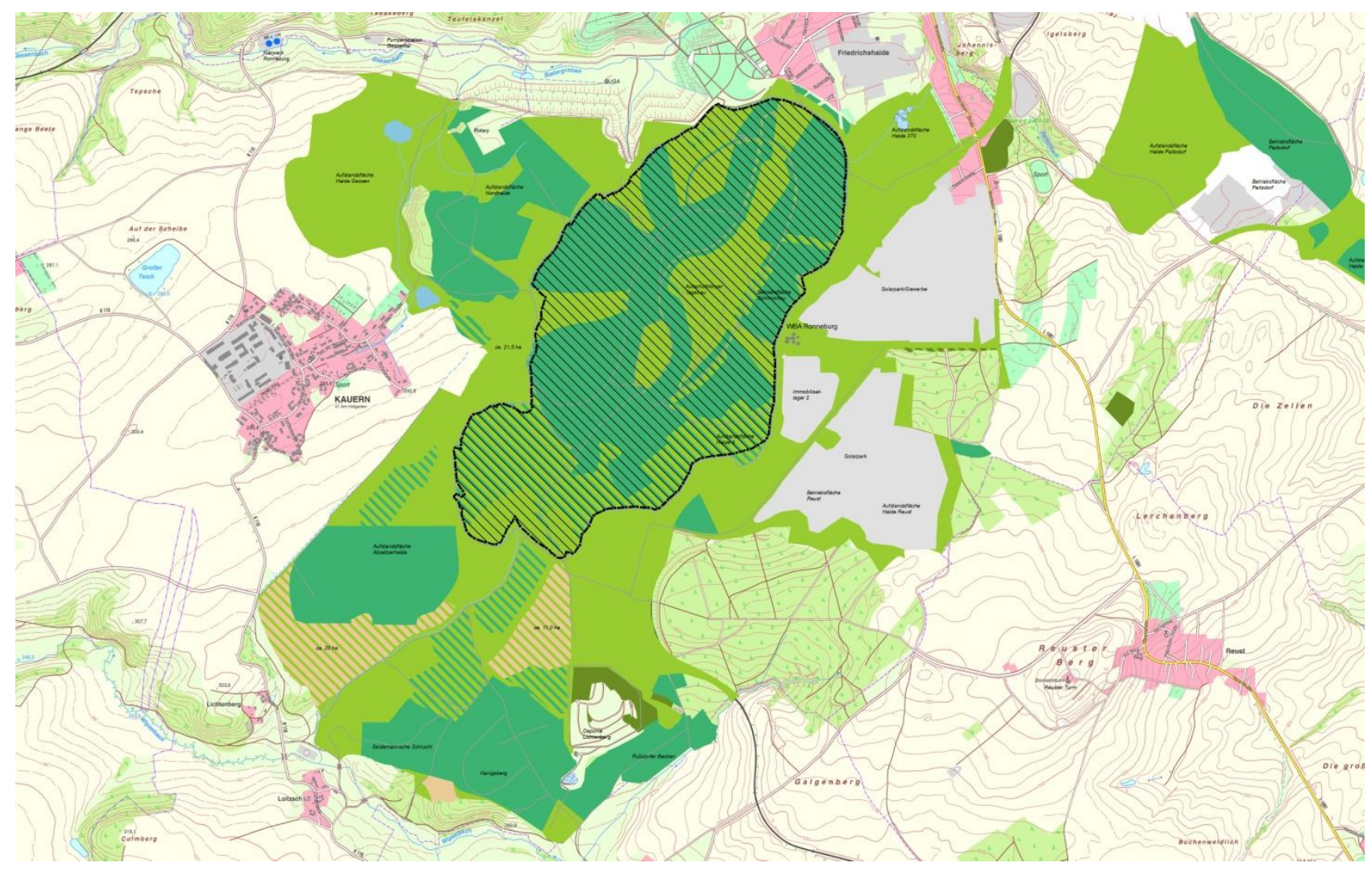

Intensive black dashed line: borderline of backfill body of Lichtenberg open pit (area with inclined hatchures); intensive colours = current or future after-use of remediated mining sites: dark green (dark grey): forest; medium green (medium grey): greenfield (grassland) allowing for succession to forest; light green (light grey) = (open) grassland (maintained); beige (with inclined hatchures): barren land (compensatory measures with respect to species conservation; intensive grey: industrial areas (factories, 2 solar power plants)

Figure 4 Lichtenberg open pit and surrounding mining sites: landscape management plans

The vegetation measures consist of erosion control seeding; establishment of mixed deciduous and coniferous forests ( $40 \%$ afforestation; $30 \%$ seeding of trees; $30 \%$ open grassland forming corridors granting a scenic view with succession to forest). The vegetated backfill and the surrounding areas separated into a mosaic of planted areas, seeded areas and areas allowing for succession. The individual areas are connected by an assemblage of connected biotopes along the main roads or walkways and along the outer rims. Diverse groups of trees with local species are being planted or sown. About $70 \%$ of the surface area is foreseen to become forest. The integration of the newly created landscape form into the surrounding area is important. Therefore open grassland is planned along specific view-axes (Figure 4) that creates attractive view points for tourism and recreation. A network of roads and walkways is needed to carry out the necessary maintenance and after care works but it also designed to provide access for the public. Figure 5 presents an aerial view of the current state of the backfilled and covered Lichtenberg area and its surrounds. The photo was taken in 2015. One can see the two solar panel plants in the foreground. The runoff retention pond $Z$ is located on the right hand side in the foreground. The berms of the newly designed artificial landscape along the Gessenbach creek valley can be seen on the right hand side in the background (Figure 5). Figure 6 shows the top plateau of the hill Schmirchauer Höhe. Here, a park was created including a $20 \mathrm{~m}$ high miner's lamp and a map indicating the former positions of shafts, waste rock dumps, and demolished villages. Figure 6 shows the park under construction. 


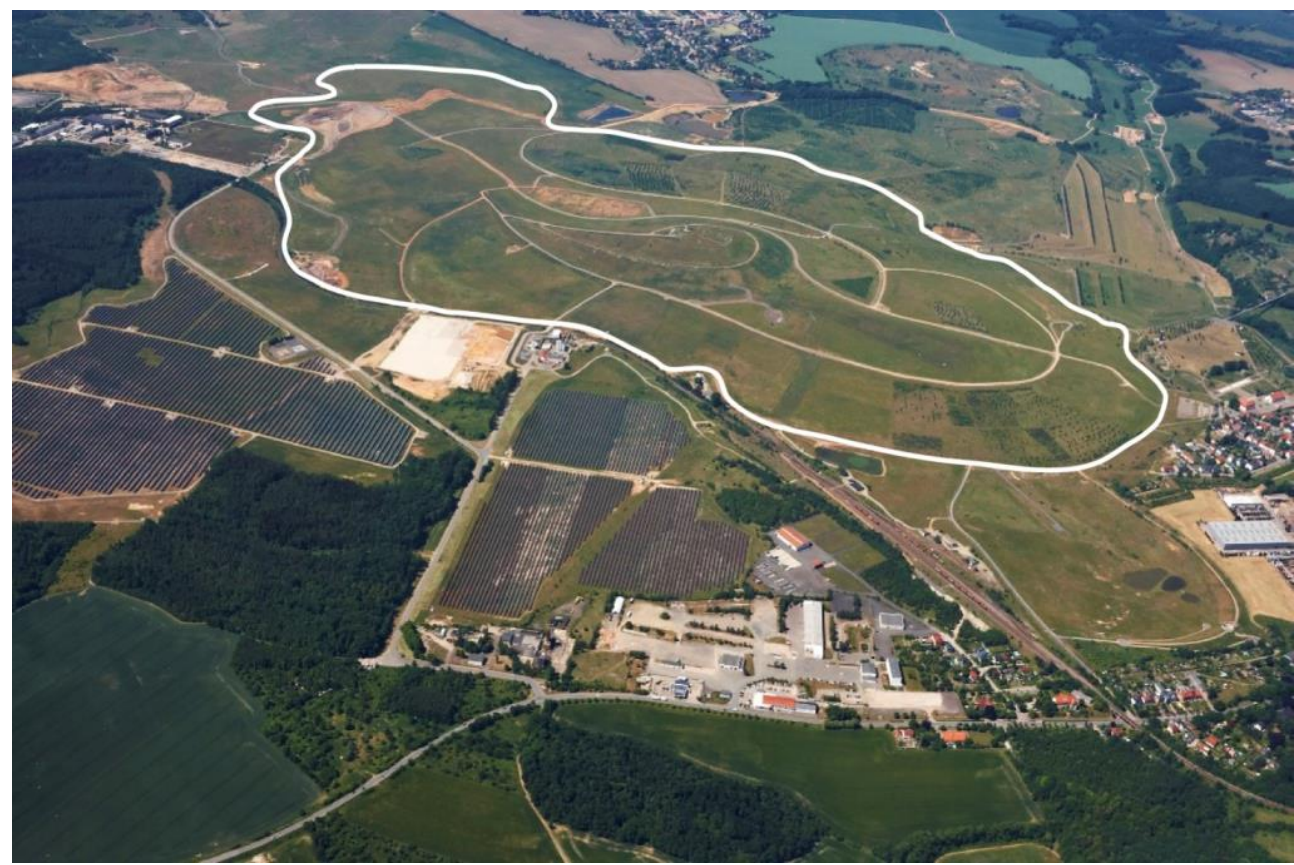

(View from northeast to southwest; solar power plants (ca. $37 \mathrm{ha}$ ) in the foreground; runoff retention pond $\mathrm{Z}$ in the foreground on the right)

Figure 5 Covered backfill body of the Lichtenberg open pit in 2015 (inside white line)

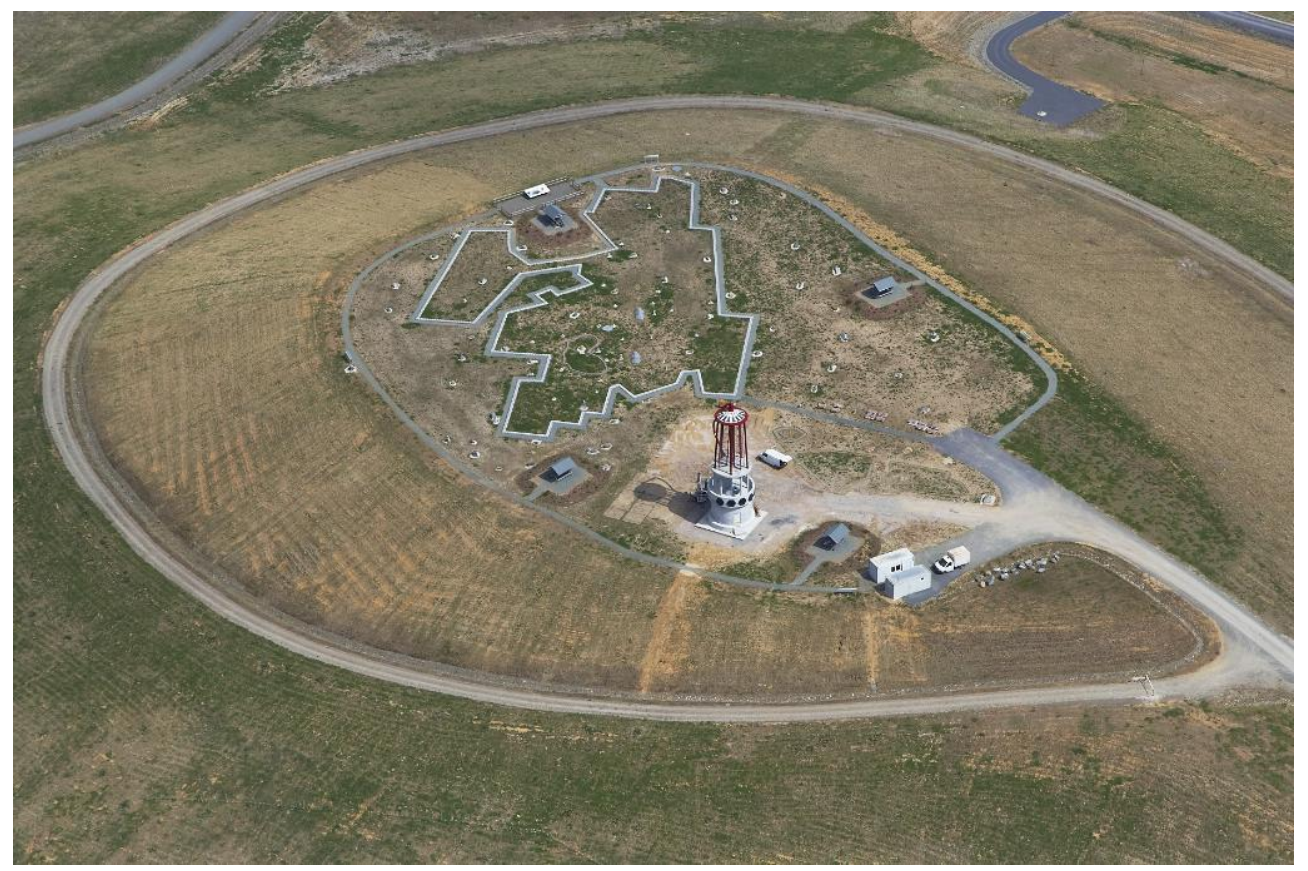

Figure 6 Top plateau of the hill Schmirchauer Höhe with park area (under construction)

\section{$5 \quad$ Soil bioengineering}

Soil bioengineering (definition in Schlüter 1996) is a sub-discipline of civil engineering, focussing on soil and hydraulic engineering, e.g. slope and embankment stabilisation, and erosion control. We can use living materials, i.e. seeds, plants, part of plants etc. sometimes as a substitute for classical engineering works. In most cases soil bioengineering provides meaningful and necessary methods of complementing the latter. It pursues technological and ecological as well as design aims.

Due to the massive destruction and rearrangement of the land uses during the mining phase, remediation is aimed at designing a new landscape using construction methods that resemble nature. The main 
objective of soil bioengineering is to support rehabilitation measures and ensure the establishment of vegetation for successful remediation (including functional stability of covers, erosional stability of surfaces etc.) and to allow further re-use of the land.

Soil bioengineering methods are used to protecting soil and secure the functionality of covers. The main objectives are the reduction of erosion, and the resurrection and improvement of soil functions. On devastated surfaces, soil bioengineering usually starts with barren raw soils characterised by a shortage of nutrients and low biological activity, in other words, quite often infertile or barren ground. Typical problems are (radioactively contaminated) dusting, very sparse vegetation and unsightly landscapes. Important soil bioengineering techniques that are applied include different types of sowing and planting species suited to the site for extensive land use.

For the remediation of the Lichtenberg open pit and its surrounding areas, three functions were to be met by the use of soil bioengineering.

\section{Physical functions of bioengineering.}

- Soil protection:

- Elimination or limitation of destructive mechanical forces.

- Protection of the soil surface from erosion by wind, precipitation, frost and flowing water.

- Reduction of flow velocity along channel banks (both riparian vegetation and engineered channel banks).

- Protection against erosion by surface runoff.

- Influencing water regime and microclimate:

- Improve local microclimatic conditions (water, temperature, wind).

- Improve cover storage capability, drainage and interception.

2. Ecological functions of bioengineering.

- Soil protection:

- Erosion control and preserving conserving soil functions.

- Improvement of nutrient content and soil fertility.

- Integration of natural vegetation processes (succession).

- Influencing water regime and microclimate:

- Decreasing the amplitude varying water flow, temperature and wind on soil.

- Improve storage capability, drainage and interception.

- Protection against emissions:

- Reduce dust, noise and urban lights.

3. Landscaping functions of bioengineering.

- Integration of landscape:

- Integration of structures into the landscape (mining sites, construction work, deposition of overburden waste).

- Concealment of visually non-appealing structures (noise protection walls).

- Enrichment of landscape:

- Creating new visual features and structures, shapes and colours of vegetation. 
The results of using soil bioengineering is living systems that will continue to develop in the future as part of the natural succession. Such site developments generally have positive economic effects as well. The economic effects of soil bioengineering are:

- Optimised costs.

- Lower construction costs during remediation compared to hard or classical engineering structures.

- Lower maintenance costs/lower after-care costs.

- Improved potential of land use.

- Creation of useable green areas and woody plant populations on previously derelict land.

- Improvement of nutrient content and soil fertility.

With a site-specific and appropriate (re-)vegetation plan, the current land use already partly compensates the collateral clauses of permits received, such as requirements regarding nature conservation or forestry commission. Soil bioengineering based on properties of the soil and natural materials is an essential part of re-utilisation of land affected by mining activities with respect to the requirements of the Federal Mining Act. Soil bioengineering is generally limited where the following conditions occur:

- Lack of water and/or high or low temperatures as critical natural limits.

- Low water storage capability.

- Arid, semi-arid, alpine and arctic regions.

- Forest, tree and shrub lines (mountains).

- Toxic materials (salt, heavy metals).

- Adverse aspect and/or exposure.

The strategy of soil bioengineering applied for the remediation of the Lichtenberg open pit and its surrounding area involved a combination of different methods, described in more detail below.

In the beginning, we based the soil bioengineering techniques on soil properties (storage capability, $\mathrm{pH}$, density, hydraulic conductivity, humus content, nutrients, amount of salt and heavy metals). The erosion risk was partially by a specifically adapted design of the surface of cover. Furthermore, we carried out different sowing methods: hydroseeding, using slope protection nets or mats, and dry sowing. Hydroseeding is particularly effective: seeds are sown on raw soil with water as the carrier medium, along with a variety of added materials like chopped straw, cellulose, glue, fertiliser, bacterial cultures and seeds. For longer distances up to $25 \mathrm{~m}$, we used hoses. Hydroseeding allows seeds to be sown on soil without any damage caused by erosion. Wismut also used mixtures of grasses and herbs (Festuca ovina, Lolium perenne, Festuca rubra, Trifolium repens) or wild flowers from the vicinity of the construction site and fertilisers to start the establishment of vegetation. Then trees, preferably autochthonous in origin could be planted. This enables Wismut to establish forests or hedges on barren soils sooner than this would occur under natural succession. Native tree species like sessile oak (Quercus petraea), sycamore maple (Acer pseudoplatanus), small-leaved lime (Tilia cordata) and European larch (Larix decidua) grow alongside hornbeam and Scots Pine (Pinus sylvestris) since the beginning of the new millennium. Temporary protection against browsing is necessary. Also, this method is expensive.

In addition we can use a great variety of bioengineering construction methods depending on the site specific conditions, like surface exposure and inclination, physical and chemical soil conditions and the timetable of the remediation works. Every site and the environmental factors there are unique and need creative solutions for success.

Figure 7 shows hydroseeding carried out on the former subsurfaces of the relocated waste rock dumps. Figure 8 shows the status of wetland biotopes established on the remediated ground surface of the former 
waste rock dump Absetzerhalde, located in the immediate vicinity of the southwestern borderline of the backfill body of the Lichtenberg open pit.

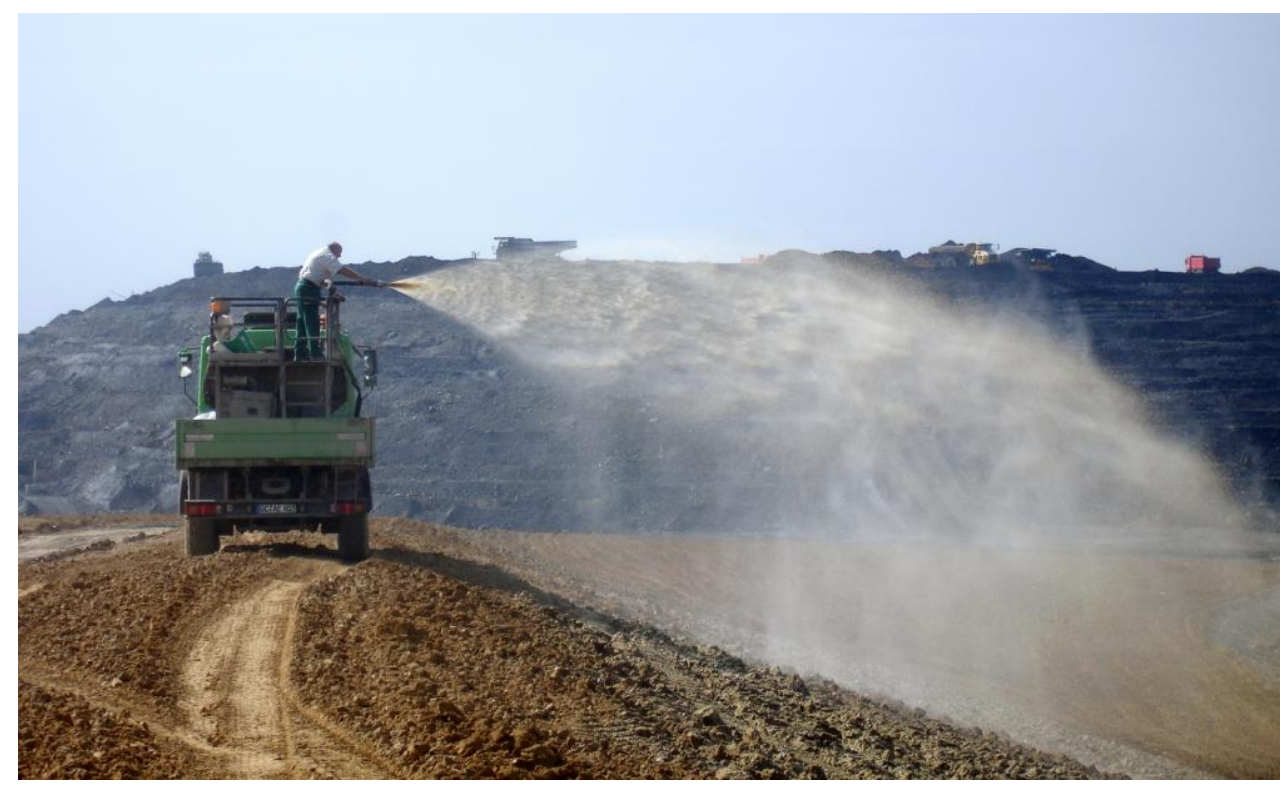

Figure 7 Hydroseeding on the subsurface of relocated dumps close to the open pit

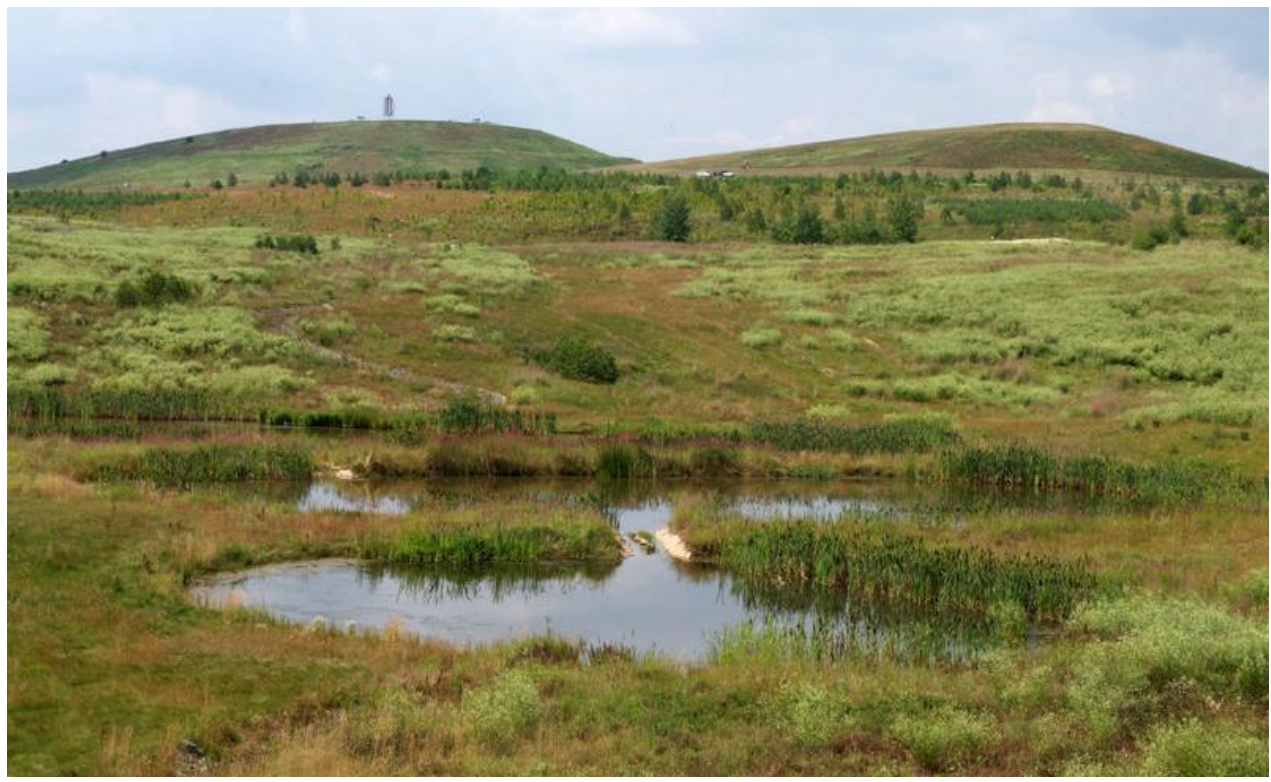

Figure 8 Wetland biotopes on remediated dump subsurfaces in 2015 in the area of runoff retention pond Z. See also the ponds on Figure 5 in the left hand side, foreground

\section{$6 \quad$ Biomonitoring}

Monitoring during and after remediation includes visual inspections, monitoring of the functionality and stability of covers (using lysimeters) on remediated sites including groundwater pathway, surface runoff, gas emanation (Radon), radiological monitoring, geodetic survey of settlements and deformations, and in particular biomonitoring. For about a decade, biomonitoring has been carried out on an annual basis including biotope mapping. Test pit excavations monitor the soil profile on a regular basis as well as root zone development in the soil cover over time. The biomonitoring details the development of vegetation, including studies on various zoological species groups, and root penetration. In addition, the stable development of established grasses, herbs and trees and their succession is an effective contribution to erosion control and (re-) vegetation of the landscape. To date, 296 plant species have settled on the cover 
of the backfilled open pit around the artificial hill Schmirchauer Höhe. Eighty-seven species have been introduced by sowing and planting. The remaining 209 species have colonised spontaneously. The flora currently forms 17 plant communities. Extended biotope networks will emerge in the coming years. The average root depth has extended to $66 \mathrm{~cm}$. To date the main root space is still only $30 \mathrm{~cm}$ due to the still young trees. The vegetation can continue to utilise a total of at least $1.6 \mathrm{~m}$ soil cover as its rhizosphere. In 2014, 48 species of birds, one reptile, one amphibian, 18 grasshopper species, 29 species of butterflies, 33 species of moths and 19 species of dragonflies were detected in the monitored area. Among them are numerous species of relevance regarding nature conservation. Important species which are under special protection by the Nature Conservation Act include, among others, swallowtail (Papilio machaon), Rare Carnation (Dianthus superbus), sand lizard (Lacerta agilis), Wheatear (Oenanthe oenanthe), Red Kite (Milvus milvus), and Woodlark (Lullula arborea). The positive assay results on ecology, botany and zoology are a testament to the rapid (re-) population of the rehabilitated or newly built landscape. Figure 9 shows a photo of a swallowtail. Figure 10 presents a photo of a sand lizard. Both pictures were taken on the monitored area of the Lichtenberg open pit.

Based on the biomonitoring results, after-care measures have been implemented continuously to initiate improve vegetation establishment and development. Nowadays some endangered species are found in the newly formed habitats.

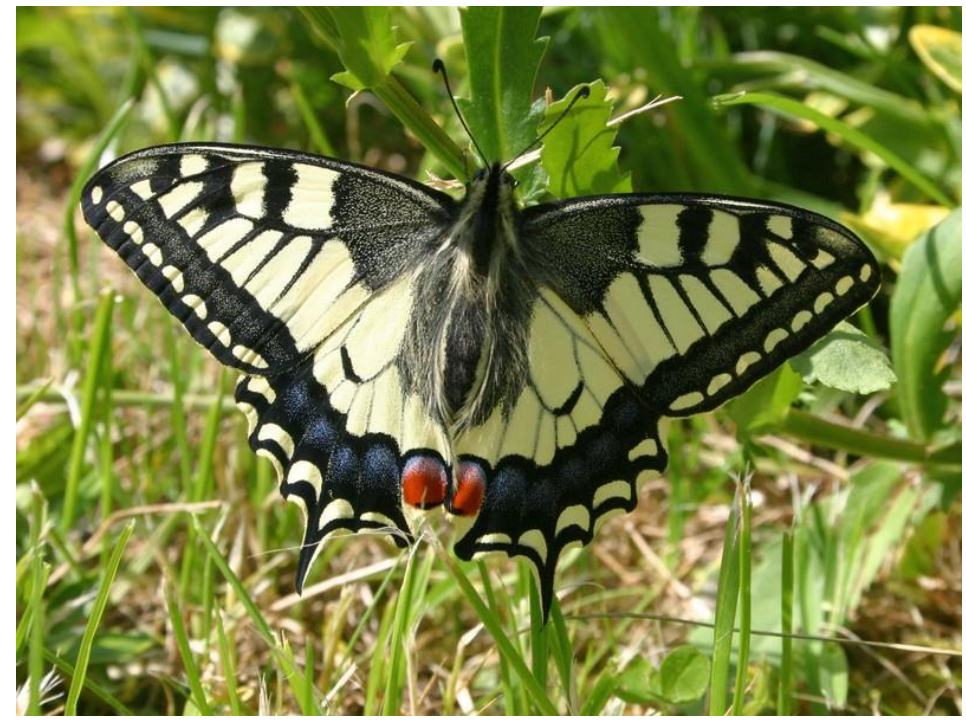

Figure 9 Swallowtail (photo by Jürgen Gräfe)

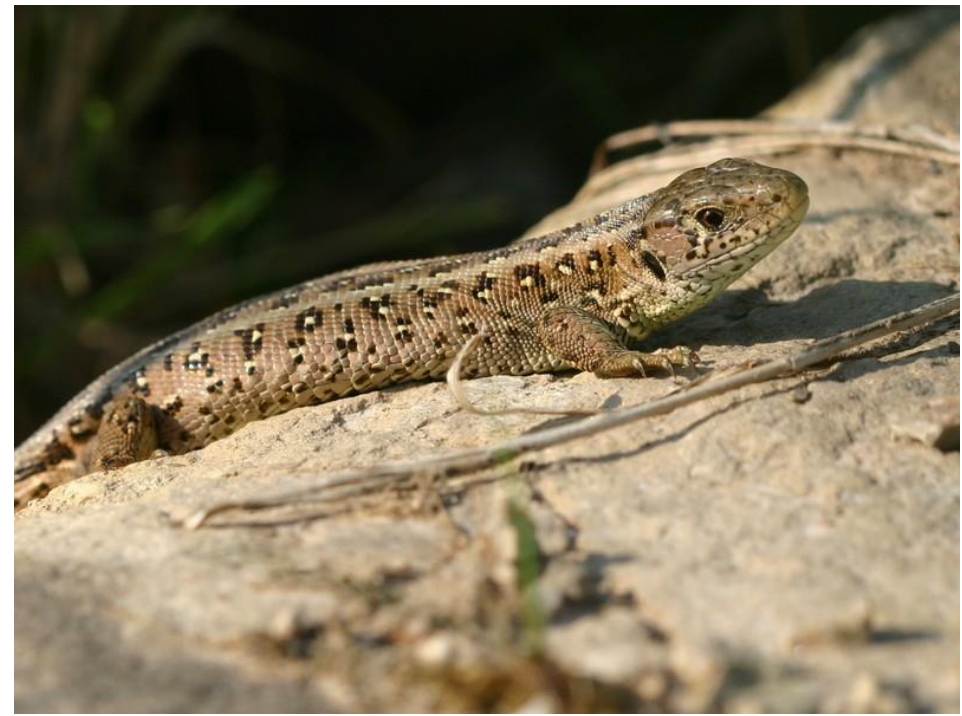

Figure 10 Sand lizard (photo by Jürgen Gräfe) 


\section{Summary}

The end of the remediation phase of the open pit Lichtenberg is a few years ahead. This allows for a preliminary overview and outlook on the constructed landscape and its after-use in the future. Following remediation strategies, the landscape of the former mining area has been completely rearranged. The cover including its vegetation on the backfilled body of the former Lichtenberg open pit that fulfils the functional stability requirements. This includes erosion control provided by a mature vegetation cover. This minimises percolation and provides sufficient plant available water content throughout the year. In addition, the remediation strategy provides sufficient protection against access to contaminated materials, avoids gas emanation (radon) and avoids any direct radiation from the underlying radioactively contaminated mine wastes. An attractive landscape has been constructed on which forest areas and open grassland successively develop. Figure 11 provides a long-term vision of the constructed landscape with fully established forests.

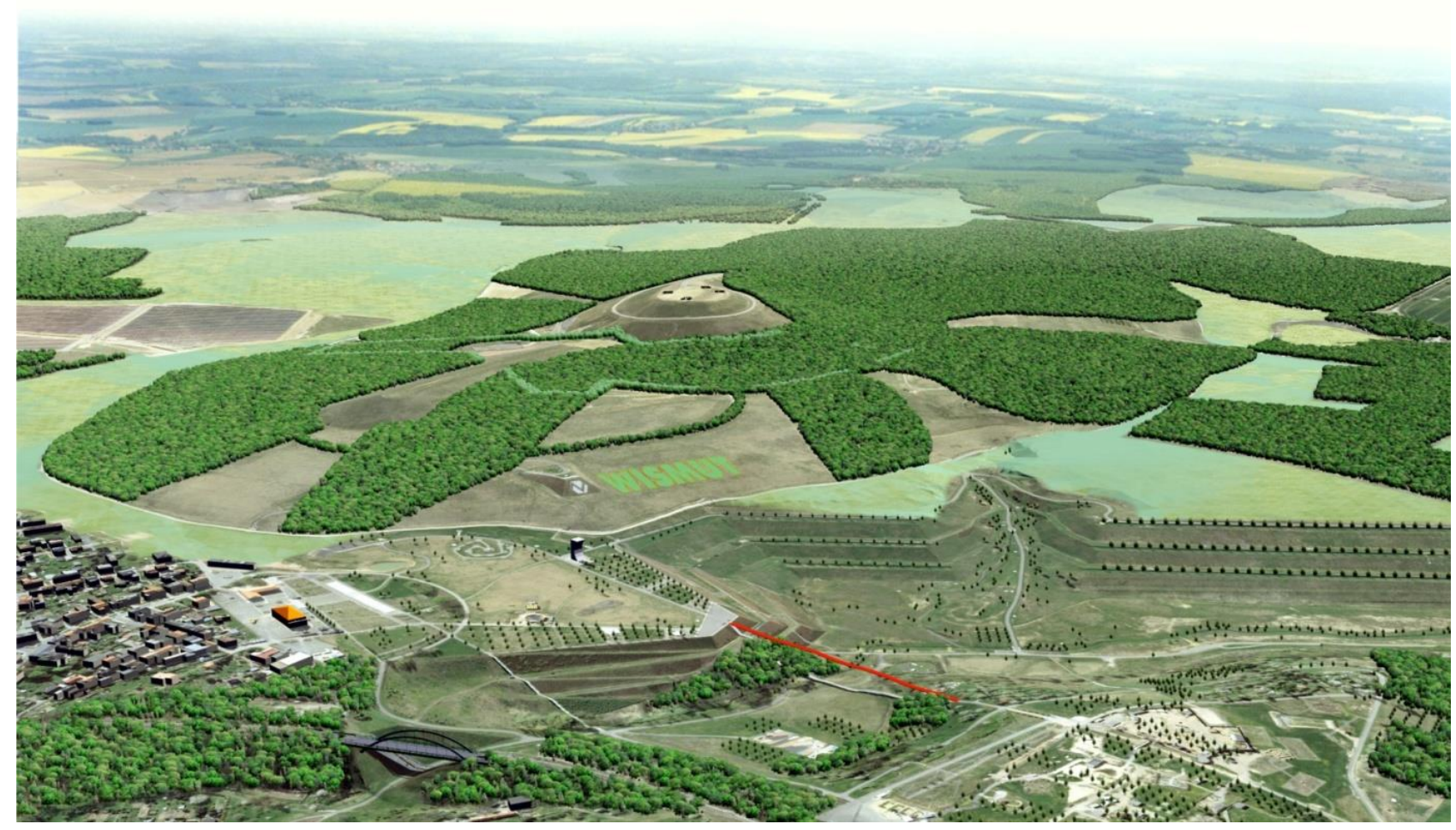

Figure 11 Vision of the new long-term constructed landscape

\section{References}

HAO 1980, 'Anordnung zur Gewährleistung des Strahlenschutzes bei Halden und industriellen Absetzanlagen und bei der Verwendung darin abgelagerter Materialien', Journal of Laws, Directive of the German Democratic Republic, p. 347. [In German]

Schlüter, U 1996, Pflanze als Baustoff: Ingenieurbiologie in Praxis und Umwelt, Patzer Verlag Berlin, Hannover. [In German]

VOAS 1984, 'Verordnung über die Gewährleistung von Atomsicherheit und Strahlenschutz', Journal of Laws, Directive of the German Democratic Republic, p. 341. [In German] 